\title{
Mechanism of Resource Sharing and Innovation Ability Based on the Moderating Role of Agglomeration-diffusion Effect
}

\author{
Yanming Sun \\ Shandong University of Science and Technology \\ Qingdao, China 266590 \\ Jilin University \\ Changchun, China 132022
}

\author{
Shukuan Zhao \\ Jilin University \\ Changchun, China 132022
}

\author{
Fasheng Liu \\ Shandong University of Science and Technology \\ Qingdao, China 266590
}

\begin{abstract}
With the development of the new generation of information technology, innovation activities become more and more open and shared. In the paper, theories of Scientific and Technological (S\&T) resources sharing and independent innovation are analyzed and enterprise's independent innovation ability is studied. The empirical results show that S\&T resource sharing has a significant positive effect on the enterprise's independent innovation ability through the moderating role of agglomeration-diffusion effect, and also has a significant positive effect on the behavior and performance of enterprise's independent innovation. The mechanism of "sharing open access" of S\&T resources play a positive role for resources to gather, diffuse, and optimized allocation, for social synergy innovation, for the ability of independent innovation of enterprises. This paper will provide relevant resources to integrate and enhance the ability of independent innovation for enterprises to develop more accurate public policy of S\&T services for the government organizations.
\end{abstract}

Keywords-resources sharing; independent innovation; agglomeration-diffusion effect; mechanism

\section{INTRODUCTION}

With the development of a new generation information technology, the integration with industry becomes more relevant and "Internet plus" will promote the improvement of information service platform and the overall intergenerational change within industry. The development in emerging information technology and transverse penetration between internet and industry, are impacting profoundly the process of enterprise management, changing

This work is funded by"Soft science of Qingdao City in 2017: Industrialization of science and technology in Qingdao", "Major financial application research project of Shandong Province in 2017: Research on application system of scientific and technological innovation achievements transformation in Shandong(CJ-2017-15)", and "National Natural Science Foundation of China: Research on the impact mechanism and coupling model of industrial technology orbit jump (71273113)". the traditional interaction of people and people, people and organization, people and resources, promoting innovation activities become more open and sharing. Therefore, this makes it imperative to build S\&T resources sharing platform based on the Internet resources, to change the traditional production and management mode, to promote the integration of Internet resources for economic and social development.

This study examines the mechanism of S\&T resources sharing on enterprise's independent innovation ability by the moderating effect of resources agglomeration-diffusion effect. This research results will provide a reference to integrate S\&T resources to improve the ability of independent innovation for enterprises, to develop more accurate public services policies for the government organizations.

\section{THEORETICAL BACKGROUND AND RESEARCH HYPOTHESIS}

\section{A. Scientific and Technological Resources Sharing and Agglomeration-diffusion Effect}

S\&T resources are foundation of innovation and collection of elements to create new achievements (Zhou Jizhong, 1999) [1], usually includes information technology, capital and human resources of science and technology activities (Ding Houde, 2005) [2]. It also can be divided into input layer (including research funds, manpower, material resources, information, technology and related policy system, etc.) and output layer (including the standardized technology patents, technology literature, S\&T products, etc.) and application layer (including new technology, new technology and new products used in the production) (Liu Lingli, 2008) [3]. S\&T resources sharing are an open sharing and dynamic system of information technology, R\&D funds, human resources and other related material 
resources in the fields of high coupling S\&T resources. Considering the principle of system dynamics, this study suggests that the process of S\&T resources sharing is a dynamic, open, and interactive and with spontaneous behavior, which contains four core links including open, access, innovation and sharing.

According to Gunnar Myrdsl's cumulative causation theory, the influencing factors move in a physical change from the center point to the outward periphery due to the presence of the transmission mechanism. The role of moderation is to provide support for the sharing of S\&T resources through the induced effects and demonstration effects. The demonstration effect has a positive effect on the spillover positive externalities of S\&T resources. Aggregation is a process of quantitative change accumulation, which emerges accompanied of "technical potential difference" caused by the aggregation effect. Technological innovation is bound to occurring agglomeration effects and diffusion effects at the same time (Deng Xiangrong, 2006) [4]. This study calls the mechanism of interaction between agglomeration and diffusion as "agglomeration diffusion effect".

In the process of technical resources sharing, the mode of resource-allocation will be changed, the traditional "closed" allocation will turn into "open" configuration, the enterprise's research and sales activities will be changed and injected the "share" elements, the agglomeration-diffusion effect of the process will affect the capability of independent innovation of enterprises significantly. The deeper the degree of sharing of S\&T resources, the more obvious the effect of agglomeration-diffusion is. In summary, this study proposes the following hypothesis:

$\mathrm{H}_{1}$ : S\&T resources sharing process has a positive impact on agglomeration-diffusion effect.

$\mathrm{H}_{1 \mathrm{a}}$ : The open access of $\mathrm{S} \& \mathrm{~T}$ resources has a positive correlation with the occurrence of agglomeration-diffusion effect.

$\mathrm{H}_{1 \mathrm{~b}}$ : The innovation and sharing of S\&T resources has positive correlation with the occurrence of agglomerationdiffusion effect.

The ability of S\&T resources sharing is a control capability of enterprise in open, access, configuration and use of S\&T resources and interaction with the outside world, including the ability to obtain resources and the ability of integration and interaction. The ability of acquisition and the ability of mutual integration for S\&T resources are complementary and interdependent. External resources need to be integrated with the internal resources to achieve value. Similarly, the enterprises need to keep a good interaction and integration with the outside world in order to continue to obtain external resources. Therefore, the ability of obtaining resources and the ability of interaction and integration intensifies the agglomeration and diffusion effect, and influences the innovation activities of enterprises. The process of resource sharing can promote the scope of agglomeration-diffusion effect, and the size of the sharing capacity determines the speed of agglomeration-diffusion effect. In summary, the following hypothesis is proposed:

$\mathrm{H}_{2}$ : The ability of S\&T resources sharing has positive effect on agglomeration-diffusion effect.

$\mathrm{H}_{2 \mathrm{a}}$ : The ability of acquisition of $\mathrm{S} \& \mathrm{~T}$ resources has a positive correlation with the occurrence of agglomerationdiffusion effect.

$\mathrm{H}_{2 \mathrm{~b}}$ : The capability of internal and external integration has positive correlation with the occurrence of agglomeration-diffusion effect.

The driving force of S\&T resources sharing is the resource providers' desire and ability to share. Ioannis (2013) proposed that the superior level of sharing and the utilization rate of resources can expand communications and mutual infiltration and alter the form and performance of S\&T resources, so as to realize the integration and innovation of S\&T resources ${ }^{[5]}$. The driving force of S\&T resources sharing is formed by market regulation mechanism, administrative policy adjustment mechanism and socio-cultural environment. Under the market mechanism, related subjects will get a reasonable economic return and be stimulated the power of sharing. In the administrative regulation, the behavior of the sharing will be regulated, the intellectual property rights and legitimate interests of stakeholders will be protected, the power of sharing will be promoted; in the social mechanism, the shared cultural values will gradually change the negative attitude of people's reluctance to share, the consciousness, behavior and power of sharing will be enhanced. Therefore, the following hypotheses are proposed.

$\mathrm{H}_{3}$ : The driving force of S\&T resources sharing has a positive effect on agglomeration-diffusion effect.

$\mathrm{H}_{3 \mathrm{a}}$ : The market regulation mechanism of S\&T resources sharing has a positive correlation with the occurrence of agglomeration-diffusion effect.

$\mathrm{H}_{3 \mathrm{~b}}$ : The administrative regulation mechanism of S\&T resources sharing has a positive correlation with the occurrence of agglomeration-diffusion effect.

$\mathrm{H}_{3 \mathrm{c}}$ : The social and cultural atmosphere of $\mathrm{S} \& \mathrm{~T}$ resources sharing has a positive correlation with the occurrence of agglomeration-diffusion effect.

\section{B. The Agglomeration-diffusion Effect of S\&T Resources Sharing and Enterprise Independent Innovation Ability}

Based on resource and dynamics capability view, enterprises must possess the capacity of technological innovation and organizational management and the ability to adapt to the environment (Damanpour, 1984) [6]. Technological innovation capability is the ability of introducing new products, new technology and improving existing products and processes (Ghoshal \& Bartlett, 1988) [7]. Enterprise independent innovation ability is a series of comprehensive characteristics of enterprise innovation strategy, including technological innovation capability, technological innovation capability and strategic management ability (Adrienne \&amp; Paula, 1989) [8]. 
From the ability structure, it mainly refers to the ability to absorb, transform and use resources (Francis, 2005) [9]. The result of independent innovation ability of enterprises is evaluation of contribution to business objectives, including performance and the people's subjective evaluation of the process and outcome (Churchill, 1992) [10].

Agglomeration and diffusion effect has the following influences on the ability of independent innovation. The external market information and technology resources transfer to the enterprise continuously, so that enterprises can easily get innovation inspiration, the introduction of a wide range of digestion and absorption of S\&T achievements, the ability of resource use and transformation of absorption. Therefore, the following hypotheses are proposed.

$\mathrm{H}_{4}$ : The agglomeration-diffusion effect of S\&T resources sharing has a positive impact on enterprise's independent innovation ability.

\section{Moderating Effect of Agglomeration-diffusion Effect}

The agglomeration-diffusion effect has a regulative impact on the sharing of S\&T resources to the process of enterprise's independent innovation ability, similar to the Domino effect, making the shared resources and achievements of science and technology transmit continuously through the sharing network structure and supply chain system. Under the moderating effect of agglomeration and diffusion, the sharing of S\&T resources is a bridge between external conditions and the demand of independent innovation of enterprises, promoting continuously the ability of enterprise independent innovation. Therefore, the following hypotheses are proposed.
$\mathrm{H}_{5 \mathrm{a}}$ : The agglomeration-diffusion effect has a positive impact on the process of S\&T resources sharing to the independent innovation ability of enterprises.

$\mathrm{H}_{5 \mathrm{~b}}$ : The agglomeration-diffusion effect has a positive impact on the ability of $\mathrm{S} \& \mathrm{~T}$ resources sharing to the independent innovation ability of enterprises.

$\mathrm{H}_{5 \mathrm{c}}$ : The agglomeration-diffusion effect has a positive impact on the dynamic of S\&T resources sharing to the independent innovation ability of enterprises.

\section{The Direct Role of S\&T Resources Sharing on the Independent Innovation Ability of Enterprises}

The sharing of S\&T resources sharing avoids resource waste and duplication, improves the resource utilization rate and the speed of the flow and transfer of knowledge, reduce the cost of enterprise innovation and the risk of innovation (Li Suicheng, 2016) [11]. In addition, the sharing provides a basic platform for collaborative innovation and interdisciplinary collaboration, offer necessary conditions for the joint research of enterprises. Finally, the sharing furnishes enterprises a new concept, new equipment, new technology, R\&D funds and talents for enterprise research. Therefore, this study proposes the following hypotheses:

$\mathrm{H}_{6 \mathrm{a}}$ : The process of $\mathrm{S} \& \mathrm{~T}$ resources sharing has a positive correlation to the enterprise independent innovation ability.

$\mathrm{H}_{6 \mathrm{a}}$ : The ability of S\&T resources sharing has a positive correlation to the independent innovation ability of enterprises.

$\mathrm{H}_{6 \mathrm{a}}$ : The dynamics of $\mathrm{S} \& \mathrm{~T}$ resources sharing is positively related to the independent innovation ability of enterprises.

In summary, the following conceptual model constructed as shown in "Fig 1".

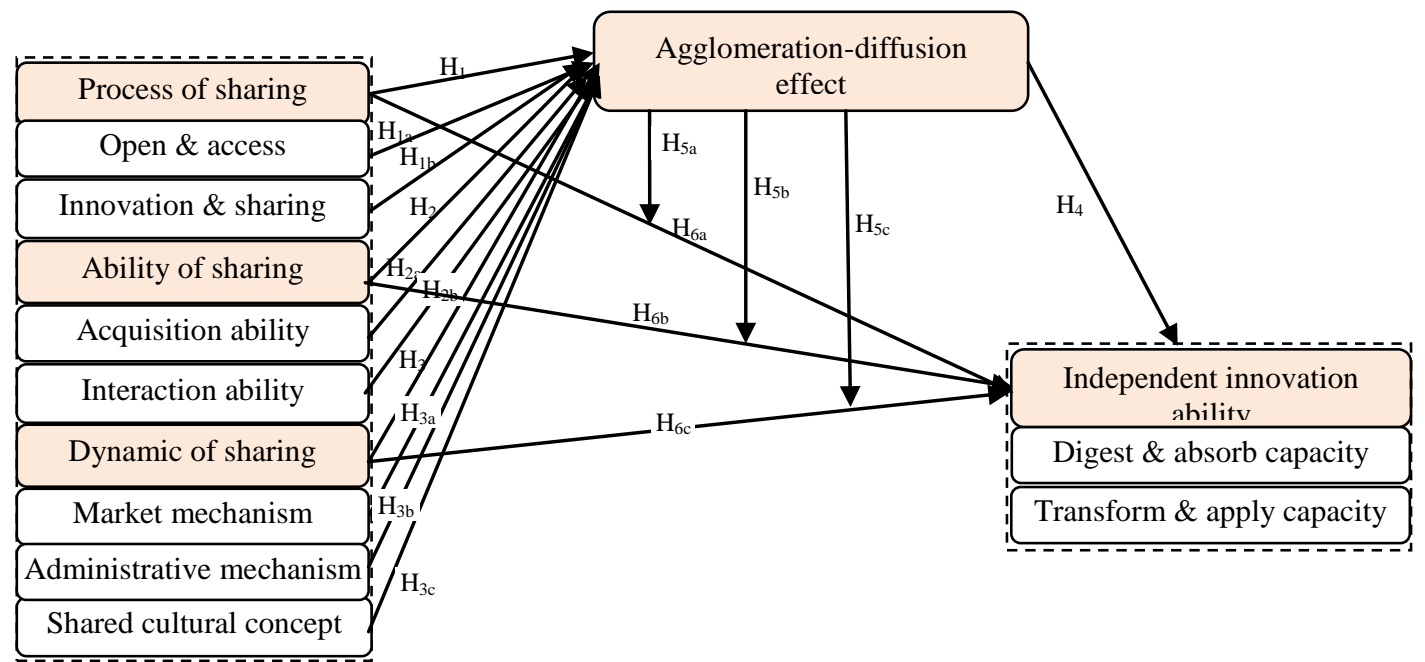

Fig. 1. Conceptual model with proposed hypotheses.

\section{RESEARCH Design AND MEthodology}

The explanatory variables are the independent innovation ability of enterprises, the independent variables are the process of resources sharing, the sharing ability and the dynamic of sharing, and the moderating variable is the concentration-diffusion effect. The variable measurement is modified based on the conceptual model and the reference 
measurement index proposed by scholars at home and abroad, and combined with the research need. With the definition and dimension of all variables, this paper proposes the model of the theory and design careful measurement terms. After encoding, the paper generated the 18 main measurement items of explanatory variables in "Table I", the 6 main measurement items of explained variables in "Table II" and 5 main measurement items of adjustment variables in "Table III". Each item assignment is used by Likert 5 level scoring method; scores from 1 to 5 indicate respectively the degree of change from low to high, from "Completely inconsistent" to "full compliance". Afterwards, statistical analysis and extraction of the survey questions is made, the reliability and validity of the questionnaire are tested by empirical test. A total of 300 questionnaires were issued, 236 were relied, 178 valid questionnaires, and the effective questionnaire rate was $59.3 \%$.

TABLE I. MEASUREMENT ITEMS OF S\&T RESOURCES SHARING

\begin{tabular}{|c|c|c|c|}
\hline Variable quantity & Dimension & $\begin{array}{l}\text { Measurement clause } \\
\end{array}$ & References \\
\hline \multirow{5}{*}{$\begin{array}{l}\text { Process of } S \& T \\
\text { resources sharing }\end{array}$} & \multirow{3}{*}{ Open \& access } & $\begin{array}{l}\text { The ways, sources, difficulty and scale of public access to S\&T } \\
\text { resources. }\end{array}$ & \multirow{5}{*}{$\begin{array}{l}\text { Zhou } \\
\text { (1999); } \\
\text { Zhong } \\
(2006)\end{array}$} \\
\hline & & $\begin{array}{l}\text { The status of access to S\&T resources, the extent of making up the gap of } \\
\text { innovation resources. }\end{array}$ & \\
\hline & & $\begin{array}{l}\text { The scope and quantity of the S\&T resources that can be used for the } \\
\text { enterprise, and the selection of the best. }\end{array}$ & \\
\hline & \multirow{2}{*}{ Innovation \& sharing } & Re-allocation, re-use, optimization and application of S\&T resources & \\
\hline & & The channels, quantity and effect of open sharing of S\&T resources & \\
\hline \multirow{5}{*}{$\begin{array}{l}\text { Ability of } S \& T \\
\text { resources sharing }\end{array}$} & \multirow{2}{*}{ Resources acquisition ability } & The extent of acquisition, utilization and assimilation of S\&T resources & \multirow{5}{*}{$\begin{array}{l}\text { Dong Baobao } \\
(2011) ; \\
\text { Zhang Laiwu (2013) }\end{array}$} \\
\hline & & The inner matching degree of S\&T resources and their utilization & \\
\hline & \multirow{3}{*}{ Interactive and fusion ability } & $\begin{array}{l}\text { The degree and effect of interaction with the outside world through the } \\
\text { participation, sharing and interaction }\end{array}$ & \\
\hline & & $\begin{array}{l}\text { The degree of opening to the outside world and accepting the outside } \\
\text { opinion in the enterprise R\&D innovation and production activities }\end{array}$ & \\
\hline & & $\begin{array}{l}\text { The effect of sharing in the innovation, innovative talents and capital and } \\
\text { other aspects of the outside world }\end{array}$ & \\
\hline \multirow{6}{*}{$\begin{array}{l}\text { Dynamics of } S \& T \\
\text { resources sharing }\end{array}$} & \multirow[t]{2}{*}{ Market driven mechanism } & $\begin{array}{l}\text { Attitudes of sharing originated from market competition pressure, } \\
\text { innovation performance and economic benefit driving }\end{array}$ & \multirow{6}{*}{$\begin{array}{l}\text { Kesler(1995); } \\
\text { Burgelman (1999); } \\
\text { Li Yingbo(2009); } \\
\text { Ioannis, N. (2013); } \\
\text { Liu Siming (2015) }\end{array}$} \\
\hline & & Willingness of sharing originated from the market transaction system & \\
\hline & \multirow{2}{*}{$\begin{array}{l}\text { Administrative adjustment } \\
\text { mechanism }\end{array}$} & $\begin{array}{l}\begin{array}{l}\text { Situation of sharing originated from administrative policy and } \\
\text { management requirements }\end{array} \\
\end{array}$ & \\
\hline & & $\begin{array}{l}\text { Willingness of sharing originated from sharing mechanism and the } \\
\text { protection of intellectual property rights }\end{array}$ & \\
\hline & \multirow{2}{*}{ Sharing culture driven } & $\begin{array}{l}\text { Degree of leading originated from the concept of shared development and } \\
\text { sustainable development }\end{array}$ & \\
\hline & & $\begin{array}{l}\text { Influence degree originated from entrepreneurial spirit, shared } \\
\text { atmosphere and shared vision }\end{array}$ & \\
\hline
\end{tabular}

a. Source: author finishing

${ }^{\text {b. }}$ Source: author finishing

TABLE II. MEASUREMENT TERMS OF ENTERPRISE INDEPENDENT INNOVATION CAPABILITY

\begin{tabular}{|c|c|c|c|}
\hline $\begin{array}{l}\text { Variable } \\
\text { quantity }\end{array}$ & Dimension & Measurement clause & References \\
\hline \multirow{6}{*}{$\begin{array}{l}\text { Independ } \\
\text { ent } \\
\text { innovatio } \\
\text { n ability }\end{array}$} & \multirow{3}{*}{$\begin{array}{l}\text { Digestion } \\
\text { and } \\
\text { absorption } \\
\text { capacity }\end{array}$} & $\begin{array}{l}\text { The effect of scanning external } \\
\text { resources, identifying the use of } \\
\text { resources and the introduction of } \\
\text { S\&T resources }\end{array}$ & \multirow{6}{*}{$\begin{array}{l}\text { Schmookler } \\
\text { J (1966); } \\
\text { Mansfield E } \\
\text { (1988); } \\
\text { Feng Gang } \\
(2013)\end{array}$} \\
\hline & & $\begin{array}{l}\text { The effect of classifying, organizing } \\
\text { and studying, digesting and } \\
\text { absorbing on S\&T resources }\end{array}$ & \\
\hline & & $\begin{array}{lcc}\text { Improve } & \text { conditions } & \text { in the } \\
\text { innovation } & \text { talent } & \text { structure, } \\
\text { innovation funds and the } \\
\text { requirement of innovation }\end{array}$ & \\
\hline & \multirow{3}{*}{$\begin{array}{l}\text { Transforma } \\
\text { tion and } \\
\text { application } \\
\text { ability }\end{array}$} & $\begin{array}{l}\text { The effect of integrating, processing } \\
\text { and optimizing distribution of the } \\
\text { S\&T resources }\end{array}$ & \\
\hline & & $\begin{array}{l}\text { The effect of innovation and } \\
\text { application of product development }\end{array}$ & \\
\hline & & $\begin{array}{l}\text { The profit expectation of innovation } \\
\text { achievement, the measurement of } \\
\text { innovation performance, operation } \\
\text { condition or market expectation }\end{array}$ & \\
\hline
\end{tabular}

TABLE III. MEASUREMENT TERMS OF AGGLOMERATION-DIFFUSION EFFECT

\begin{tabular}{|c|c|c|c|}
\hline $\begin{array}{l}\text { Variable } \\
\text { quantity }\end{array}$ & Dimension & Measurement clause & References \\
\hline \multirow{5}{*}{$\begin{array}{c}\text { Agglomerati } \\
\text { on- } \\
\text { diffusion } \\
\text { effect of } \\
\text { S\&T } \\
\text { resources }\end{array}$} & \multirow{3}{*}{$\begin{array}{l}\text { Induced } \\
\text { effect }\end{array}$} & $\begin{array}{l}\text { The flow velocity and the } \\
\text { extent of resources } \\
\text { distribution in the process } \\
\text { of S\&T resources sharing }\end{array}$ & \multirow{5}{*}{$\begin{array}{l}\text { Damanpour } \\
\text {,F.E. } \\
\text { \&William } \\
\text { (1984); } \\
\text { Ghoshal, S. } \\
\text { \& Bartlett, } \\
\text { C.A. (1988) }\end{array}$} \\
\hline & & $\begin{array}{l}\text { The degree of non- } \\
\text { balanced development of } \\
\text { S\&T resources sharing }\end{array}$ & \\
\hline & & $\begin{array}{l}\text { Transmission mechanism } \\
\text { and network structure of } \\
\text { S\&T resources sharing }\end{array}$ & \\
\hline & \multirow{2}{*}{$\begin{array}{l}\text { Demonstrat } \\
\text { ion effect }\end{array}$} & $\begin{array}{l}\text { The difficulty level of } \\
\text { technology introduction, } \\
\text { organization learning and } \\
\text { imitation innovation }\end{array}$ & \\
\hline & & $\begin{array}{l}\text { The degree of positive } \\
\text { externalities of } \begin{array}{l}\text { S\&T } \\
\text { resources }\end{array}\end{array}$ & \\
\hline
\end{tabular}




\section{EMPIRICAL PROCESS}

\section{A. Test of Reliability and Validity}

Before the hypothesis verified, the internal consistency reliability, the convergent validity and the discriminant validity of the measurement model are tested by the
Cronbach coefficient, to ensure the specific concept of the scale proper and sufficiently. As shown in "Table IV", the exploratory factor analysis results of all variables are given, it can be seen that all factor loadings and reliability are more than 0.7, which is in line with the acceptable level of the relevant studies suggest, which indicates that the scale has good reliability and internal consistency reliability.

TABLE IV. TEST RESUlts OF RELIABILITY AND VALIDITY OF VARIABLES

\begin{tabular}{|c|c|c|c|c|c|}
\hline Variables & Factors & Factor load (validity) & $\begin{array}{l}\text { Reliability } \\
\text { (Alpha value) }\end{array}$ & The value of KMO & Cumulative factor \\
\hline \multirow{2}{*}{$\begin{array}{c}\text { Process of } S \& T \\
\text { resources sharing }\end{array}$} & Open \& access & 0.841 & \multirow{2}{*}{0.812} & 0.834 & \multirow{2}{*}{68.251} \\
\hline & Innovation \& sharing & 0.769 & & 0.732 & \\
\hline \multirow{2}{*}{$\begin{array}{l}\text { Ability of } S \& T \text { resources } \\
\text { sharing }\end{array}$} & Resources acquisition ability & 0.831 & \multirow{2}{*}{0.786} & 0.771 & \multirow{2}{*}{74.916} \\
\hline & Interactive and fusion ability & 0.772 & & 0.845 & \\
\hline \multirow{3}{*}{$\begin{array}{l}\text { Dynamics of } S \& T \\
\text { resources sharing }\end{array}$} & Market driven mechanism & 0.718 & \multirow{3}{*}{0.767} & 0.848 & \multirow{3}{*}{69.132} \\
\hline & Administrative adjustment mechanism & 0.703 & & 0.734 & \\
\hline & Sharing culture driven & 0.701 & & 0.768 & \\
\hline \multirow{2}{*}{$\begin{array}{c}\text { Agglomeration- } \\
\text { diffusion effect }\end{array}$} & Induced effect & 0.745 & \multirow{2}{*}{0.781} & 0.896 & \multirow{2}{*}{80.973} \\
\hline & Demonstration effect & 0.813 & & 0.857 & \\
\hline \multirow{2}{*}{$\begin{array}{c}\text { Independent innovation } \\
\text { ability }\end{array}$} & Digestion and absorption capacity & 0.823 & \multirow{2}{*}{0.773} & 0.862 & \multirow{2}{*}{79.218} \\
\hline & Transformation and application ability & 0.811 & & 0.781 & \\
\hline
\end{tabular}

\section{B. Confirmatory Factor Analysis}

Confirmatory factor analysis not only shows the scale has good validity, but also supports our division of factor dimensions from empirical. According to the related theory and the analysis of the test scale, the paper conducts confirmatory factor analysis using AMOS 7 statistical software, judges whether the measurement model of this study matches the data by fitting exponential of the model. The results shown in "Table V" showed that the five factor model was in good agreement with the data, and all the factor loads reached the significant level.

TABLE V. FITTING INDEX OF CONFIRMATORY FACTOR ANALYSIS

\begin{tabular}{|c|c|c|c|c|c|c|c|}
\hline & $\mathbf{X}^{2}$ & df & $X^{2} / d f$ & SRMR & CFI & TLI & RMSEA \\
\hline Five-factor model & 419.615 & 183 & 2.67 & 0.046 & 0.907 & 0.921 & 0.067 \\
\hline Three-factor model $^{a}$ & 732.221 & 273 & 3.92 & 0.071 & 0.729 & 0.753 & 0.079 \\
\hline Two-factor model ${ }^{b}$ & 916.198 & 317 & 4.94 & 0.092 & 0.581 & 0.658 & 0.092 \\
\hline Single factor model $^{c}$ & 1131.521 & 382 & 5.81 & 0.102 & 0.386 & 0.318 & 0.112 \\
\hline
\end{tabular}

Note: ${ }^{a}$ The process of sharing, the ability of sharing and the dynamic of sharing merge into a potential factor; ${ }^{b}$ The process of sharing, the ability of sharing, the dynamic of sharing and the agglomeration-diffusion effect merge into a potential factor; ${ }^{\mathrm{c}}$ All variables merge into a potential factor.

\section{Simple Correlation Analysis}

Pearson correlation analysis was used to detect the variables in the model. As shown in "Table VI", according to the relevant criteria, the process of S\&T resources sharing, the ability of S\&T resources sharing and the dynamic of S\&T resources sharing has more significant positive correlation with the agglomeration-diffusion effect, which has a positive correlation to the ability of independent innovation of enterprises, at the same time, the process, the ability and the dynamic of S\&T resources sharing also has more significant positive correlation with the ability of independent innovation of enterprises. This indicates that the conceptual model and research hypothesis of this study is more reasonable.

TABLE VI. DESCRIPTIVE StATISTICS OF VARIABLES AND PEARSON CORRELATION MATRIX

\begin{tabular}{|c|c|c|c|c|c|c|c|c|c|}
\hline Variables & 1 & 2 & 3 & 4 & 5 & 6 & 7 & 8 & 9 \\
\hline 1. Enterprise age & 1 & & & & & & & & \\
\hline 2. Industry type & -.088 & 1 & & & & & & & \\
\hline 3. Enterprise scale & -.044 & .131 & 1 & & & & & & \\
\hline 4. Enterprise nature & -.040 & -.051 & .081 & 1 & & & & & \\
\hline 5. Process of $S \& T$ resources sharing & .091 & .046 & .101 & .101 & 1 & & & & \\
\hline 6. Ability of $S \& T$ resources sharing & -.041 & $-.019^{*}$ & $-.036^{*}$ & $.011^{* *}$ & .061 & 1 & & & \\
\hline 7. Dynamic of $S \& T$ resources sharing & -.082 & -.074 & -.052 & .054 & $.039^{*}$ & .087 & 1 & & \\
\hline 8. Agglomeration- diffusion effect & .112 & -.293 & .058 & $.041^{*}$ & $.011^{* *}$ & $.037^{*}$ & $.023^{* *}$ & 1 & \\
\hline 9. Independent innovation ability & -.039 & $.206^{*}$ & .085 & .062 & $.039^{*}$ & $.015^{* *}$ & $.041^{*}$ & $.011^{* * *}$ & 1 \\
\hline Mean value $(M)$ & 8.78 & .56 & 2.78 & 2.53 & 3.56 & 3.38 & 3.21 & 3.49 & 3.87 \\
\hline Standard deviation $(S D)$ & 5.32 & .40 & 1.02 & 0.67 & 0.68 & 0.60 & 0.63 & 0.65 & 0.77 \\
\hline
\end{tabular}




\section{Hypothesis Validation and Results}

According to the conceptual model and research hypotheses of this study, using multiple linear regression analysis, the relationship between the process of sharing, the ability of sharing, the dynamic of sharing and the innovation ability of enterprises is validated.

The empirical results shows that non standardized regression coefficients of the process, the ability and the dynamic of S\&T resources sharing are $0.34,0.36,0.19$ respectively, significant $\mathrm{P}$ values is less than 0.05 , which indicate that the three variables have a significant positive impact on enterprise independent innovation ability, the results supported the original hypothesis $\mathrm{H}_{5 \mathrm{a}}, \mathrm{H}_{5 \mathrm{~b}}$ and $\mathrm{H}_{5 \mathrm{c}}$. By not considering the agglomeration-diffusion effect, nonstandardized regression coefficients that the process, the ability and the dynamic of sharing directly corresponding to the enterprise independent innovation ability are $0.25,0.27$, 0.17 , significant $\mathrm{P}$ values are all less than 0.05 , the results supported the original hypothesis $\mathrm{H}_{6 \mathrm{a}}, \mathrm{H}_{6 \mathrm{~b}}$ and $\mathrm{H}_{6 \mathrm{c}}$, which indicate that the process, the ability and the dynamic of sharing directly affect the ability of independent innovation, but the degree of influence is weaker than the degree of the action of regulation variables, but also reflects the moderating role of agglomeration-diffusion effect is more significant. Therefore, the enterprises should actively participate in the sharing of S\&T resources, actively absorb external achievements in product innovation, technology innovation, R\&D innovation and market development, actively share the resources, process and achievements of innovation, follow and maintain the operation mechanism of "Open, access and sharing" of S\&T resources, so as to create a favorable external cooperation condition for promoting the ability of independent innovation.

\section{CONCLUSION}

Based on the theoretical model and the moderating role of agglomeration-diffusion effect, this study analyzes the relationship between the process, the ability, the dynamic of S\&T resources sharing and the ability of enterprise independent innovation. The main conclusions are as follows.

Firstly, there is a significant positive correlation between the process, the ability, the dynamics of S\&T resources sharing and the diffusion effect and the ability of independent innovation. To increase the degree of sharing and utilization of S\&T resources can promote mutual exchange, penetration, coordination and supplement, improve efficiency of integration and optimal allocation of S\&T resources. Secondly, the S\&T resources sharing can come into being a significant agglomeration diffusion effect, which plays a regulatory function by induced effect, demonstration effect and external effect, promotes the flow, transfer, diffusion, absorption, integration, transformation and innovation of S\&T resources among different subjects of enterprises, colleges and universities, scientific research institutes and governments, helps to improve the ability of enterprise independent innovation. Thirdly, there is an operation mechanism of "open, access and sharing "of S\&T resources, referred to as the "OAS" mechanism, which come into being under the combined action of the market mechanism, administrative regulation mechanism and sharing culture concept, act on the activities of enterprise independent innovation.

\section{REFERENCES}

[1] Zhou Jizhong. Scientific and technological resources. Shanxi people's education press, 1999:132-136.

[2] Ding Houde. New problems and countermeasures in the allocation of scientific and technological resources. Science of science, 2005, 23(4):474-480.

[3] Liu Lingli. Research on the connotation, classification and characteristics of scientific and technological resource elements. Journal of information science, 2008(8):125-126.

[4] Deng Xiangrong, Liu Xuan. A comparative study on the effect of innovation polarization and diffusion in Jingjinji Region and Yangtze River Delta. China Science and Technology Forum,2007(11):16-20.

[5] Ioannis, N., Nikolaos, A., and Zoe,V.(2013) 'Modeling gender evolution and gap in science and technology using ecological dynamics', Expert Systems with Applications,no.40,pp.3481-3490.

[6] Damanpour,F.E.and William, M.(1984)‘Organizational innovation and performance: the problem of organizational lag', Administrative Science Quarterly,No.29,pp.392-409.

[7] Ghoshal, S. and Bartlett, C.A. (1988) 'Creation, adoption, and diffusion of innovations by subsidi', Journal of International Business Studies, Vol.19, No.3,pp.365-388.

[8] Adrienne, E.E. and Paula, B.V. (1989) 'The ability of unions to adapt to innovative workplace arrangements', The American Economic Review,Vol.79, No.2, pp.172-176.

[9] Francis, D.B.(2005) 'Targeting innovation and implications for capability development', Technovation,2005, Vol.25, No.3, pp.171183.

[10] Churchill G Ford N,Walker O,Sales Force Management.Homewood,1992.

[11] Li Suicheng, Wu Mengchao. The impact of supplier integration capabilities on incremental innovation and breakthrough innovation, Technological progress and countermeasures, 2016(2),96-102.

[12] Zhong Bingrong. Integration of Scientific and Technological resources, promoting the development of local science and technology, Technical and economic. 2006(7):10-12.

[13] Li Yingbo, Resource allocation of science and technology innovation mechanism, mode and route choice. Beijing Economic Science Press, 2009.14-19.

[14] Chen Zhijun et al. Influence of the external innovation source on innovation performance: the moderating effect of absorptive capacity. Economic management. 2014(3).

[15] Cui Miao, Su Jingqin. Driving force of Chinese enterprises management innovation: A comparison with Western companies. Science of science, 2012(5):755-765.

[16] Schmookler J. Invention and economic growth. Cambridge: Harvard University Press, 1966.

[17] Mansfield E. Industrial innovation in Japan and the United States Science, 1988, 24(1):49-61.

[18] Schumpeter J A. The Theory of Economic Development. Boston: Harvard University Press, 2004.

[19] Burgelman. Personal initiative sparks innovation. Research Technology Management,1999(3):61-71.

[20] Kesler.Innovation Milieu and Regional Policy Enterpreneurship and Reginal Development.Research Technology Management, 1995(7):157-163. 